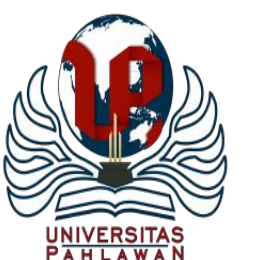

Jurnal Basicedu Volume 4 Nomor 3 Tahun 2020 Halm. 681 - 689

JURNAL BASICEDU

Research \& Learning in Elementary Education

https://jbasic.org/index.php/basicedu

\title{
Pengembangan Multimedia Interaktif Berbasis Pendekatan SETS Untuk Meningkatkan Kemampuan Berpikir Kritis Siswa Sekolah Dasar
}

\author{
Fandu Zakariya Firdaus ${ }^{1}$, Suryanti ${ }^{2}$, Utiya Azizah $^{3}$ \\ Universitas Negeri Surabaya, Jawa Timur, Indonesia ${ }^{1,2,3}$ \\ e-mail: $\underline{\text { fandu.18080@mhs.unesa.ac.id }{ }^{1}}$
}

\begin{abstract}
Abstrak
Penelitian ini bertujuan untuk mengetahui kelayakan multimedia interaktif berbasis pendekatan SETS untuk meningkatkan kemampuan berpikir kritis siswa kelas IV sekolah dasar yang meliputi kevalidan, kepraktisan dan keefektifan. Penelitian ini menggunakan model 4D. Model pengembangan ini terdiri dari empat tahapan; pendefinisian (define), perancangan (design), pengembangan (develop), dan penyebaran (disseminate). Subjek penelitian ini adalah 20 siswa kelas IV SDN Klakahrejo I/578 Kota Surabaya. Uji coba dilakukan dengan menggunakan One Group Pretest-Posttest Design. Pengumpulan data dilakukan melalui validasi, pengamatan, tes, dan angket respon siswa. Data hasil penelitian yang diperoleh sebagai berikut: (1) kevalidan multimedia interaktif berbasis SETS yang dikembangkan mendapat skor rata-rata 3,75 dengan kategori sangat valid; (2) kepraktisan multimedia interaktif berbasis SETS dapat dilihat dari keterlaksanaan RPP dengan skor rata-rata keterlaksanaan RPP sebesar 3,70 berkategori sangat baik dan aktivitas siswa yang mengalami peningkatan dari pertemuan ke pertemuan.; (3) keefektifan multimedia interaktif berbasis SETS dapat dilihat dari respon siswa yang positif dan sebagian besar skor N-Gain yang diperoleh menunjukkan kategori tinggi. Berdasarkan hasil penelitian, dapat disimpulkan bahwa multimedia interaktif berbasis pendekatan sets untuk meningkatkan kemampuan berpikir kritis siswa kelas IV sekolah dasar telah valid, praktis, dan efektif.

Kata kunci: multimedia interaktif, pendekatan SETS, kemampuan berpikir kritis
\end{abstract}

\begin{abstract}
The purpose of this research to know the feasibility of interactive multimedia based on a sets approach to improve the critical thinking skills of grade IV elementary school students a valid, practical and effective. This research uses the 4D model. This development model consists of four stages; define, design, develop, and disseminate. The subjects of this research were 20 fourth grade students of SDN Klakahrejo I/578 Surabaya. Testing was conducted using One Group Pretest-Posttest Design. Data collection is done by validation, observation, tests, and student questionnaire responses. The research data obtained as follows: (1) validity of interactive multimedia based on SETS gets an average score of 3.75 with a very valid category; (2) practicality of interactive multimedia based on SETS can be seen from the implementation of the RPP with an average score of RPP implementation of 3.70 categorized as very good and student activities that have increased from meeting to meeting; (3) the effectiveness of interactive multimedia based on SETS can be seen from the positive student responses and most of the $N$-Gain scores obtained indicate a high category. Based on the research results, it can be concluded that interactive multimedia based on sets approach to improve the critical thinking skills of grade IV elementary school students is valid, practical, and effective.
\end{abstract}

Keywords: interactive multimedia, SETS approach, critical thinking skills

Copyright (c) 2020 Fandu Zakariya Firdaus, Suryanti, Utiya Azizah

$\triangle$ Corresponding author :

Address : -

Email : fandu.18080@mhs.unesa.ac.id

ISSN 2580-3735 (Media Cetak)

DOI: 10.31004/basicedu.v4i3.417

ISSN 2580-1147 (Media Online) 


\section{PENDAHULUAN}

Perkembangan zaman yang semakin maju ditandai dengan semakin berkembangnya ilmu pengetahuan dan teknologi. Salah satu ilmu pengetahuan yang mendasari perkembangan teknologi adalah Ilmu Pengetahuan Alam (IPA). Menurut Susanto (2013, p.167) IPA adalah usaha manusia dalam memahami alam semesta melalui pengamatan yang tepat sasaran, menggunakan prosedur, dan dijelaskan dengan penalaran sehingga mendapatkan suatu kesimpulan. Pembelajaran IPA di SD ditujukan untuk memberi kesempatan siswa memupuk rasa ingin tahu secara alamiah, mengembangkan kemampuan bertanya dan mencari jawaban atas fenomena alam berdasarkan bukti, serta mengembangkan cara berpikir ilmiah. Aspek penting yang harus diperhatikan guru dalam pelaksanaan pembelajaran IPA di SD adalah melibatkan siswa secara aktif dalam pembelajaran untuk mengembangkan kemampuan berpikirnya.

Berpikir terjadi dalam setiap aktivitas mental manusia, berfungsi untuk memformulasikan atau menyelesaikan masalah, membuat keputusan serta mencari alasan. Salah satu kemampuan berpikir yang harus dikembangkan pada diri siswa adalah kemampuan berpikir kritis. Abidin et al. (2017, p.229) menjelaskan. bahwa berpikir kritis merupakan kemampuan yang digunakan dalam memutuskan berbagai informasi yang didapat secara logis dan kreatif, untuk selanjutnya digunakan dalam menganalisis, mengevaluasi, dan membuat kesimpulan akhir. Tujuan berpikir kritis adalah: (1) pemahaman akan suatu masalah dapat ditingkatkan; (2) tepat dalam memilih solusi yang berguna; (3) menghindari keyakinan yang salah; (4) meminimalkan kesalahan dalam mengambil suatu keputusan; dan (5) bermanfaat dalam memilih, menilai, dan memodifikasi ide-ide baru Surya (2013, p.161). Dalam berpikir kritis terdapat indikator yang harus dicapai siswa. Menurut Ennis dalam Costa \& Presseisen, (1985) terdapat lima indikator berpikir kritis, yaitu memberikan penjelasan sederhana (elementary clarification), membangun keterampilan dasar (basic support), menyimpulkan (interfence), membuat penjelasan lebih lanjut (advance clarification), serta strategi dan taktik (strategy and tactics).

Maulana (2017, p. 5) menjelaskan terdapat beberapa alasan mengapa berpikir kritis perlu dikembangkan pada pembelajaran abad ke-21 yaitu: (1) tuntutan perkembangan zaman yang menghendaki siswa untuk mampu menggunakan informasi, mencari, dan memilih solusi yang tepat dalam kehidupan; (2) pemecahan masalah agar siswa mampu secara adil berkompetisi dengan baik; (3) mampu mengatasi berbagai masalah dan pilihan dengan cara berpikir kritis. Kemampuan berpikir kritis merupakan keterampilan berpikir tingkat tinggi yang harus dibiasakan dan dikuasai siswa dalam mengembangkan kemampuan kognitifnya (Badan Standar Nasional Pendidikan, 2010, p. 44; Maulana, 2017, p. 4). Hal ini sesuai dengan pendapat Sari \& Sugiyarto (2015) bahwa siswa perlu dibiasakan dalam berpikir kritis untuk dapat digunakan dalam menyelidiki dan mengungkap persoalan yang akan dihadapi dalam 
kehidupan sehari-hari, salah satunya melalui penggunaan media pembelajaran yang dapat meningkatkan kemampuan berpikir kritis siswa.

Berdasarkan hasil observasi dan wawancara awal kepada tiga guru kelas IV dan empat siswa kelas IV pada tanggal 21 Oktober 2019 di SDN Klakahrejo I/578, diperoleh hasil observasi dan wawancara yang mengacu pada aspek media pembelajaran dan evaluasi pembelajaran, ditemui beberapa temuan yaitu: (1) kesulitan guru dalam menyiapkan media pembelajaran yang relevan; dan (2) kurangnya pembiasaan kemampuan berpikir kritis dalam evaluasi pembelajaran.

Faktor penyebab pembelajaran IPA di SD belum dapat memberikan hasil seperti yang diharapkan yaitu berpangkal pada kurikulum, penggunaan pendekatan yang kurang tepat ataupun pembuatan atau pemilihan media dalam pembelajaran. Pernyataan tersebut diperkuat dengan hasil penelitian Krissandi \& Rusmawan (2015, p. 457) menyatakan bahwa permasalahan yang dialami di SD mencakup kesulitan dalam pembuatan media pembelajaran yang relevan, pengorganisasian antar muatan pelajaran dalam sebuah tema, serta penguasaan teknologi informasi.

Dalam proses pembelajaran IPA belum banyak guru yang menciptakan kondisi dan situasi yang memungkinkan siswa untuk berpikir kritis. Hal ini terlihat dalam kegiatan belajar mengajar guru menjelaskan materi yang telah disiapkan kemudian memberikan latihan soal yang bersifat hafalan materi.
Untuk menyelesaikan masalah tersebut diperlukan suatu pendekatan pembelajaran yang dapat melatihkan siswa untuk berpikir kritis dalam menemukan pemecahan permasalahan. Ada beberapa pendekatan yang dapat diterapkan dalam pembelajaran IPA SD, salah satunya adalah pendekatan SETS (Science, Environment, Technology, and Society). Pendekatan SETS merupakan pembelajaran terpadu yang diharapkan mampu membelajarkan peserta didik untuk memiliki kemampuan memandang secara terintegrasi dengan memperhatikan empat unsur yaitu IPA, lingkungan, teknologi dan masyarakat (Binadja, 1999; Khasanah, 2015, p. 271). Guru dapat mengaitkan konsep-konsep sains yang diajarkan dengan persoalan-persoalan yang terjadi di masyarakat dan lingkungan sehari-hari sehingga membantu siswa dalam menerapkan hasil belajar di sekolah dalam kehidupan sehari-hari (Afifah et al., 2014, p. 17). Menurut Setiyono (2011), kegiatan pembelajaran bervisi SETS dapat melatihkan keterampilan berpikir kritis dan berpikir kreatif siswa. Senada dengan pendapat tersebut Oktaviani et al. (2017) menyatakan perangkat pembelajaran bervisi SETS valid, efektif, dan praktis digunakan sebagai alat bantu model PBL serta dapat meningkatkan kemampuan berpikir kritis dan keterampilan sosial pada kelas eksperimen. Sintaks pendekatan Science, Technology, and Society (STS) terdiri dari lima tahap yaitu tahap invitasi, pembentukan konsep, aplikasi konsep, pemantapan konsep, dan penilaian (Poedjiadi, 2010, p. 126). 
Pendekatan SETS ini diintegrasikan dalam multimedia interaktif. Hal ini bertujuan untuk menciptakan pembelajaran yang menyenangkan dan bermakna bagi siswa. Vaughan (2006) mengatakan bahwa multimedia merupakan kombinasi antara teks, seni, suara, animasi, dan video yang disampaikan melalui komputer atau peralatan elektronika dan digital. Multimedia interaktif merupakan suatu multimedia yang dilengkapi dengan alat pengontrol yang dapat dioperasikan oleh pengguna, sehingga pengguna dapat memilih apa yang dikehendaki untuk proses selanjutnya (Daryanto, 2010, p. 49). Susilana et al. (2007, p. 18) mengatakan bahwa manfaat multimedia yaitu akan memberi manfaat proses pembelajaran lebih menarik, lebih interaktif, jumlah waktu mengajar dapat dikurangi, kualitas belajar siswa dapat ditingkatkan dan proses belajar mengajar bisa dilakukan di mana saja dan kapan saja, serta sikap belajar siswa dapat ditingkatkan.

\section{METODE}

Penelitian dan pengembangan (research \& development) merupakan model penelitian yang dipilih dalam penelitian ini. Styosari (2016, p. 277) menjelaskan penelitian pengembangan merupakan rangkaian tindakan yang digunakan dalam memvalidasi dan mengembangkan suatu produk. Model pengembangan yang dipilih menggunakan model 4D yang dikembangkan oleh Thiagarajan et al. (1974, p. 5). Model pengembangan ini terdiri dari empat tahapan; pendefinisian (define), perancangan (design), pengembangan (develop), dan penyebaran (disseminate). Subjek dalam penelitian ini ialah 20 siswa kelas IV SDN Klakahrejo I/578 Kota Surabaya tahun ajaran 2019/2020. Rancangan penelitian saat uji coba menggunakan One Group Pretest-Posttest Design. Rancangan ini melibatkan satu kelompok yang di observasi pada tahap pre-test (01) yang dilanjutkan dengan perlakuan tertentu (x) dan post-test (02) (Sugiyono, 2015). Teknik pengumpulan data untuk penelitian ini adalah observasi, angket respon siswa, angket validasi ahli media dan ahli materi serta penilaian berpikir kritis. Instrumen yang digunakan dalam penelitian ini adalah sebagai berikut: 1) instrumen Kelayakan Multimedia Interaktif, 2) instrumen Kepraktisan Multimedia Interaktif, dan 3) instrumen Keefektifan Media.

\section{HASIL DAN PEMBAHASAN}

Penelitian ini dilaksanakan dengan tujuan mengembangkan multimedia interaktif berbasis pendekatan SETS yang valid, praktis, dan efektif.

\section{Kelayakan Multimedia Interaktif}

Tabel 1 Hasil Rekapitulasi Validasi Multimedia Interaktif

\begin{tabular}{ccc}
\hline $\begin{array}{c}\text { Rata-rata } \\
\text { penilaian }\end{array}$ & $\begin{array}{c}\text { Persetage of } \\
\text { Agreement }\end{array}$ & Kategori \\
3,75 & $93,88 \%$ & $\begin{array}{c}\text { Sangat } \\
\text { Valid }\end{array}$ \\
\hline
\end{tabular}

Berdasarkan hasil validasi multimedia interaktif tersebut menunjukkan bahwa multimedia interaktif berbasis SETS yang dikembangkan mendapat skor rata-rata 3,75 dengan kategori sangat valid. Persentase multimedia interaktif berbasis SETS adalah 93,88\%. Skor tersebut 
mengindikasikan bahwa multimedia interaktif berbasis SETS sangat layak digunakan.

\section{Kepraktisan Multimedia Interaktif Berbasis Pendekatan SETS}

Kepraktisan multimedia interaktif berbasis SETS dapat dilihat dari keterlaksanaan RPP dan aktivitas siswa diamati oleh dua pengamat.

1. Keterlaksanaan Rencana Pelaksanaan Pembelajaran (RPP)

Hasil pengamatan keterlaksanaan kegiatan pembelajaran dengan menggunakan multimedia interaktif berbasis SETS yang sudah dikembangkan akan dilakukan analisis pada setiap pertemuan yang dijelaskan secara rinci pada tabel 2

Tabel 2 Hasil Rekapitulasi Keterlaksanaan RPP

\begin{tabular}{ccc}
\hline $\begin{array}{c}\text { Rata-rata } \\
\text { penilaian }\end{array}$ & $\begin{array}{c}\text { Persetage of } \\
\text { Agreement }\end{array}$ & Kategori \\
3,70 & $93,02 \%$ & Sangat \\
& & Baik \\
\hline
\end{tabular}

Berdasarkan Tabel 2 secara umum dapat dilihat bahwa rata-rata pengamatan keterlaksanaan RPP pada kelas uji coba berkategori sangat baik dengan skor rata-rata keterlaksanaan RPP sebesar 3,70 dan persentase rata-rata skor yang diperoleh diatas 75\%. Hal ini dapat diartikan bahwa pengelolaan pembelajaran dengan menggunakan pendekatan SETS berjalan dengan sangat baik. Pembelajaran berpusat pada siswa sehingga siswa aktif dalam proses belajar di kelas, dan guru memfasilitasi siswa dengan baik.

2. Hasil Analisis Aktivitas Belajar Siswa

Aktivitas siswa dalam proses pembelajaran diamati oleh dua orang pengamat. Pengamatan dilakukan selama proses pembelajaran berlangsung, dari awal sampai akhir pembelajaran. Jenis aktivitas siswa yang diamati oleh pengamat sebanyak 8 (delapan).

Pada pertemuan pertama, kedua, dan ketiga aktivitas siswa mendengarkan dan memperhatikan guru menjelaskan memiliki persentase rata-rata $82,4 \%$; mengeksplorasi isu atau masalah $85,6 \%$; mengidentifikasi isu dalam masyarakat memiliki rata-rata persentase sebesar 83,9\%; analisis isu memiliki persentase rata-rata $87,5 \%$; memberikan solusi terhadap permasalahan memiliki persentase rata-rata $85,6 \%$; menyimpulkan memiliki persentase rata-rata 88,6\%; mengomunikasikan hasil kerja memiliki persentase rata-rata $85,8 \%$; dan mengajukan pertanyaan dan berpendapat memiliki persentase rata-rata $85,0 \%$.

\section{Keefektifan Multimedia Interaktif Berbasis}

1. Respon Siswa

Angket respon siswa diberikan pada siswa setelah uji akhir. Secara umum respon siswa terhadap multimedia interaktif berbasis pendekatan SETS dan perangkat pembelajaran yang dikembangkan menunjukkan hasil persentase rata-rata diatas $75 \%$ yang berarti 
sebagian besar siswa memberikan respon positif atau sangat kuat sedangkan sisanya merupakan respon kurang senang dan menarik terhadap pembelajaran yang dilakukan.

2. Hasil Tes Kemampuan Berpikir Kritis

Soal diujicobakan pada 20 siswa kelas IV di SDN Klakahrejo I untuk mengetahui tingkat validitas dan reliabilitas butir soal. Dalam penelitian ini, uji validitas dilakukan untuk mengetahui tingkat kesahihan alat ukur. Validitas soal diolah menggunakan korelasi product moment dengan bantuan SPSS Version 21.

Tabel 3 Hasil Uji Validitas Soal Kemampuan Berpikir Kritis

\begin{tabular}{lccc}
\hline & $\begin{array}{c}\text { r hitung } \\
\left(\mathbf{r}_{\mathbf{x y}}\right)\end{array}$ & r tabel & Keterangan \\
\hline A.1 & 0,508 & 0,378 & Cukup valid \\
A.2 & 0,498 & 0,378 & Cukup valid \\
A.3 & 0,679 & 0,378 & Valid \\
A.4 & 0,540 & 0,378 & Cukup valid \\
A.5 & 0,725 & 0,378 & Valid \\
A.6 & 0,543 & 0,378 & Cukup valid \\
A.7 & 0,629 & 0,378 & Valid \\
A.8 & 0,726 & 0,378 & Valid \\
A.9 & 0,582 & 0,378 & Cukup valid \\
A.10 & 0,507 & 0,378 & Cukup valid \\
\hline
\end{tabular}

Setelah dilakukan uji validitas, 10 soal yang telah valid selanjutnya dilakukan uji reliabilitas soal. Uji reliabilitas menggunakan korelasi Alfa Chronbach's diolah menggunakan bantuan software SPSS Version 21. Hasil uji reliabilitas butir soal menunjukkan reliabilitas sebesar $0,788>$ 0,600, dikarenakan nilai karena nilai Alpa >
0,600, sehingga butir soal dapat dikatakan reliabel.

\section{Uji Normalitas}

Uji normalitas digunakan untuk menguji apakah data berdistribusi normal atau tidak. Uji normalitas data tes kemampuan berpikir kritis dengan teknik one sample kolmogorov-smirnov pada taraf signifikansi 0,05 pada program SPSS 21. Berdasarkan tabel 4 menunjukkan bahwa data berdistribusi normal sudah terpenuhi terlihat dari taraf signifikan pada variabel pretest dan posttest pada kelas ujicoba lebih dari 0,05 atau 5\%.

Tabel 4 Hasil Uji Normalitas Kelas Ujicoba OneSample Kolmogorov-Smirnov Test

\begin{tabular}{|ll|r|r|}
\hline & & $\begin{array}{r}\text { Pretest uji } \\
\text { coba }\end{array}$ & $\begin{array}{r}\text { Posttest } \\
\text { uji coba }\end{array}$ \\
\hline $\mathrm{N}$ & Mean & 53.2500 & 86.0000 \\
Normal & Std. & 12.16931 & 8.82580 \\
Parameters, & Deviation & & \\
Most & Absolute & .160 & .125 \\
Extreme & Positive & .132 & .115 \\
Differences & Negative & -.160 & -.125 \\
Kolmogorov-Smirnov Z & .718 & .558 \\
Asymp. Sig. (2-tailed) & .682 & .914 \\
\hline
\end{tabular}

a. Test distribution is Normal.

b. Calculated from data.

\section{Hasil Evaluasi Tes Berpikir Kritis}

Indikator berpikir kritis yang peneliti terapkan pada penelitian ini adalah memberikan penjelasan sederhana, membangun keterampilan 
dasar, mengatur strategi dan taktik, dan menyimpulkan. Penilaian kemampuan berpikir kritis dilakukan sebelum pembelajaran (pretest) dan setelah pembelajaran (posttest). Pemberian pretest bertujuan untuk mengetahui kemampuan awal siswa sedangkan posttest diberikan untuk mengetahui kemampuan siswa setelah mengikuti proses pembelajaran dengan menggunakan multimedia interaktif berbasis pendekatan SETS. Adapun hasil data capaian berpikir kritis tiap indikator.

Tabel 5 Data Capaian Berpikir Kritis Tiap Indikator

\begin{tabular}{|c|c|c|c|c|c|}
\hline \multirow[b]{2}{*}{ No } & \multirow[b]{2}{*}{ Indikator } & \multicolumn{2}{|c|}{ Pretest } & \multicolumn{2}{|c|}{ Postest } \\
\hline & & Skor & $\begin{array}{c}\text { Kate } \\
\text { gori }\end{array}$ & Skor & $\begin{array}{c}\text { Kate } \\
\text { gori }\end{array}$ \\
\hline 1 & $\begin{array}{l}\text { Memberikan } \\
\text { Penjelasan } \\
\text { Sederhana }\end{array}$ & 57,08 & $\begin{array}{l}\text { Tidak } \\
\text { Tunta } \\
\text { s }\end{array}$ & 87,08 & $\begin{array}{c}\text { Tunta } \\
\mathrm{s}\end{array}$ \\
\hline 2 & $\begin{array}{l}\text { Membangun } \\
\text { Keterampila } \\
\text { n Dasar }\end{array}$ & 52,50 & $\begin{array}{c}\text { Tidak } \\
\text { Tunta } \\
\text { s }\end{array}$ & 88,75 & $\begin{array}{c}\text { Tunta } \\
\mathrm{s}\end{array}$ \\
\hline 3 & $\begin{array}{l}\text { Menyimpul } \\
\text { kan }\end{array}$ & 52,50 & $\begin{array}{c}\text { Tidak } \\
\text { Tunta } \\
\text { s }\end{array}$ & 81,25 & $\begin{array}{c}\text { Tunta } \\
\text { s }\end{array}$ \\
\hline 4 & $\begin{array}{l}\text { Mengatur } \\
\text { Strategi dan } \\
\text { Taktik }\end{array}$ & 49,38 & $\begin{array}{l}\text { Tidak } \\
\text { Tunta } \\
\text { s }\end{array}$ & 85,00 & $\begin{array}{c}\text { Tunta } \\
\text { s }\end{array}$ \\
\hline
\end{tabular}

Berdasarkan tabel 5 diperoleh informasi bahwa terjadi peningkatan skor tiap indikator berpikir kritis sebelum dan setelah pembelajaran dengan menggunakan multimedia interaktif berbasis pendekatan SETS.

Analisis hasil tes berpikir kritis menggunakan $N$-Gain. $N$-Gain digunakan untuk menghitung besarnya peningkatan kemampuan berpikir kritis. Adapun hasil skor tes kemampuan berpikir kritis siswa sebagai berikut.
Tabel 6 Skor Tes Berpikir Kritis Siswa Kelas Ujicoba

\begin{tabular}{|l|l|c|c|c|c|}
\hline \multirow{2}{*}{ No } & \multirow{2}{*}{$\begin{array}{l}\text { Nama } \\
\text { Siswa }\end{array}$} & Pretest & Postest & $\begin{array}{c}\text { G- } \\
\text { Gain } \\
\text { skor }\end{array}$ & \\
\hline 1 & AS & 60,0 & 92,5 & 0,81 & Tinggi \\
\hline 2 & AFR & 60,0 & 95,0 & 0,88 & Tinggi \\
\hline 3 & ABP & 60,0 & 95,0 & 0,88 & Tinggi \\
\hline 4 & AA & 62,5 & 87,5 & 0,67 & Sedang \\
\hline 5 & ACP & 75,0 & 92,5 & 0,70 & Tinggi \\
\hline 6 & ARD & 45,0 & 82,5 & 0,68 & Tinggi \\
\hline 7 & APR & 40,0 & 77,5 & 0,63 & Sedang \\
\hline 8 & ANA & 40,0 & 82,5 & 0,71 & Tinggi \\
\hline 9 & AM & 45,0 & 80,0 & 0,64 & Tinggi \\
\hline 10 & AMD & 60,0 & 90,0 & 0,75 & Tinggi \\
\hline 11 & BP & 65,0 & 95,0 & 0,86 & Tinggi \\
\hline 12 & BAA & 45,0 & 85,0 & 0,73 & Sedang \\
\hline 13 & CAP & 55,0 & 90,0 & 0,78 & Tinggi \\
\hline 14 & CAO & 60,0 & 97,5 & 0,94 & Tinggi \\
\hline 15 & FWH & 30,0 & 70,0 & 0,57 & Sedang \\
\hline 16 & KAG & 37,5 & 70,0 & 0,52 & Sedang \\
\hline 17 & MKB & 55,0 & 85,0 & 0,67 & Tinggi \\
\hline 18 & MJG & 75,0 & 95,0 & 0,80 & Tinggi \\
\hline 19 & NLP & 47,5 & 87,5 & 0,76 & Tinggi \\
\hline 20 & NAA & 47,5 & 70,0 & 0,43 & Sedang \\
\hline
\end{tabular}

Berdasarkan Tabel 6 diperoleh informasi bahwa rata-rata skor kemampuan berpikir kritis yang dicapai siswa kelas ujicoba setelah pretest adalah 53,25, sedangkan berdasarkan skor postest terdapat peningkatan pada rata-rata nilai kemampuan berpikir kritis yaitu 86,00. Peningkatan kemampuan Berpikir Kritis dapat dilihat dari N-Gain skor tes Berpikir Kritis berkisar antara 0,7-1. Modus N-Gain hasil tes Berpikir Kritis siswa kelas ujicoba berada pada kategori 
tinggi, ditunjukkan dengan peningkatan skor pada pretest dan postest. Hal ini menunjukkan bahwa penerapan multimedia interaktif berbasis pendekatan SETS dapat meningkatkan Berpikir Kritis siswa pada materi energi. Senada dengan penelitian tersebut Djamas et al. (2018) menyatakan bahwa pengembangan multimedia interaktif dilengkapi dengan permainan dapat meningkatkan kemampuan berpikir kritis siswa.

\section{SIMPULAN}

Berdasarkan temuan hasil penelitian dapat disimpulkan bahwa multimedia interaktif berbasis pendekatan SETS yang dikembangkan layak, praktis, dan efektif digunakan untuk meningkatkan kemampuan berpikir kritis siswa.

\section{DAFTAR PUSTAKA}

Abidin, Y., Mulyati, T., \& Yunansah, H. (2017). PEMBELAJARAN LITERASI: Strategi Meningkatkan Kemampuan Literasi Matematika, Sains, Membaca, Dan Menulis. Bumi Aksara.

Afifah, R., Rusilowati, A., \& Supriyadi. (2014). Keefektifan Model Pembelajaran Guided Discovery Dengan Media Question Cards Bervisi SETS Dalam Membelajarkan Kebencanaan Alam Terintegrasi Dalam IPA. Unnes Physic Education Jurnal, 3(1). https://doi.org/https://doi.org/10.15294/upej.v 3i1.3099

Badan Standar Nasional Pendidikan. (2010). Paradigma Pendidikan Nasional Abad XXI.

Binadja, A. (1999). Hakekat dan Tujuan Pendidikan SETS (Sci- ence, Environment, Technology, and Society). Seminar Lokakarya Nasional Pendidikan SETS Untuk Bidang Sains Dan Non Sains.
Costa, A. L., \& Presseisen, B. Z. (1985). Glossary of Thinking Skill, in A.L. Costa (ed). Developing Minds: A Resource Book for Teaching Thinking. ASCD.

Daryanto. (2010). Media Pembelajaran. Gava Media.

Djamas, D., Tinedi, V., \& Yohandri. (2018). Development of interactive multimedia learning materials for improving critical thinking skills. International Journal of Information and Communication Technology Education, 14(4), 66-84. https://doi.org/10.4018/IJICTE.2018100105

Khasanah, N. (2015). SETS sebagai Pendekatan Pembelajaran IPA Modern pada Kurikulum 2013. 270-277.

Krissandi, A. D. S., \& Rusmawan, R. (2015). Kendala Guru Sekolah Dasar Dalam Implementasi Kurikulum 2013. Jurnal Cakrawala Pendidikan, XXXIV(3), 457-467. https://doi.org/10.21831/cp.v3i3.7409

Maulana. (2017). Konsep dasar matematika dan pengembangan kemampuan berpikir kritiskreatif. UPI Sumedang Press.

Oktaviani, P., Hartono, \& Marwoto, P. (2017). Pengembangan Multimedia Interaktif Bervisi SETS sebagai Alat Bantu Model Problem Based Learning (PBL) dalam Pembelajaran IPA di SMP untuk Meningkatkan Kemampuan Berpikir Kritis dan Keterampilan Sosial Peserta Didik. PSEJ (Pancasakti Science Education Journal), 2(2), 125. https://doi.org/10.24905/psej.v2i2.746

Poedjiadi, A. (2010). Sains Teknologi Masyarakat: Model Pembelajaran Kontekstual Bermuatan Nilai. PT Remaja Rosdakarya.

Sari, D. S., \& Sugiyarto, K. H. (2015). Pengembangan Multimedia Berbasis Masalah Untuk Meningkatkan Motivasi Belajar Dan Kemampuan Berpikir Kritis Siswa. Jurnal Inovasi Pendidikan IPA, I(2), 153-166. 
689 Pengembangan Multimedia Interaktif Berbasis Pendekatan SETS Untuk Meningkatkan Kemampuan Berpikir Kritis Siswa Sekolah Dasar - Fandu Zakariya Firdaus, Suryanti, Utiya Azizah DOI: 10.31004/basicedu.v4i3.417

https://doi.org/10.21831/jipi.v1i2.7501

Setiyono, F. P. (2011). Pengembangan perangkat pembelajaran kimia kelarutan dan hasil kali kelarutan (Ksp) dengan pendekatan SETS untuk meningkatkan kemampuan berpikir kritis dan kreatif siswa. Jurnal Penelitian Pendidikan, 1(2), 149-158.

Styosari, P. (2016). Metode penelitian pendidikan \& pengembangan. Prenemedia Grup.

Sugiyono. (2015). Metode penelitian \& pengembangan: research and development. Alfabeta.

Surya, H. (2013). Cara belajar orrang genius. PT Elek Media Komputindo.

Susanto, A. (2013). Teori Belajar dan Pembelajaran di Sekolah Dasar. Kencana Prenada Media Group.

Susilana, Rudi, \& Riyana, C. (2007). Media Pembelajaran. Wacana Prima.

Thiagarajan, S., Semmel, D. ., \& Semmel, M. . (1974). Instructional development for training teachers of exceptional children: A sourcebook. In Eric (Ed.), Journal of School Psychology. University Bloomington. https //files.eric.ed.gov/fulltext/ED090725

Vaughan, T. (2006). Multimedia: Making It Work Eighth Edition. In Tay Vaughan. https://doi.org/10.2298/VSP0602169S 